\title{
Analisis Kemampuan Membaca Siswa Pada Pembelajaran Reading Comprehension
}

\author{
Musahrain $^{10}$, Nunuk Suryani11, Suharno ${ }^{12}$ \\ musahrain_fpbs@yahoo.com
}

Abstract: This study aimed to determine the ability of students' reading comprehension in grade XI SMA Negeri Kota Bima, the factors that affect the students' reading comprehension comprehension, as well as obstacles and how to overcome them. The type of research used in this research was qualitative research using observation, interview and documentation study. The data collection technique involved 74 students of class XI in SMA Negeri Kota Bima as respondents. While for data analysis technique, the writer uses triangulation of data and sources. From this research, it resulted: (1) Based on the results of student learning evaluation conducted by teachers during the last 2 years, the average score obtained by students of 60, 28 of them got score with a high value ranges 70-100, and the remaining got 46 scores with a score range of 10-65; (2) Factors that may affect student reading comprehension were internal and external factors; (3) As for some obstacles encountered in this research were: (a) The use of instructional media by teachers was still lacking, (b) the utilization of facilities and infrastructure had not been maximized, (c) the learning resources were still lacking, (d) the student' motivation was low, (4)The solutions offered were: (a) Maximum utilization of facilities and infrastructure, (b)the use texts in the form of local folklore, (d) using and develop innovative, lightweight, easy and repeatable media of learning.

Keywords: Reading, Learning, Reading Comprehension.

\footnotetext{
10 Mahasiswa Magister Teknologi Pendidikan Universitas Sebelas Maret Surakarta

11 Dosen Universitas Sebelas Maret Surakarta

12 Dosen Universitas Sebelas Maret Surakarta
} 


\section{PENDAHULUAN}

ndonesia merupakan salah satu negara kepulauan yang memiliki jenis atau ragam bahasa terbanyak didunia. Namun ditengah banyaknya ragam bahasa yang digunakannya, Indnesia memiliki satu bahasa kesatuan, bahasa nasional yaitu bahasa Indonesia.

Bahasa merupakan salah satu aspek yang paling penting dan krusial dalam kehidupan manuasi. Karena dengan bahasa orang bisa saling berinteraksi atau berkomunikasi antara satu sama lain, baik itu lewat, tulisan, lisan maupun lewat gerakan tubuh atau yang biasa disebut dengan body language.

Untuk dapat memahami sebuah bahasa, tentu kita harus banyak mengumpulkan atau memperoleh referensi. Dalam pengumpulan referensi ini juga tentu banyak cara, metode ataupun tehnik yang dilakukan. Beda orang tentu beda pula tehnik atau metode yang digunkannya. Ada yang meperoleh dengan cara mengamati atau menyimak, berinteraksi dengan orang lain, dan ada juga yang memperolehnya dengan cara membaca, baik itu bahasa daerah, bahasa nasional maupun bahasa Internasional.

Berbicara mengenai bahasa Internasional (Bahasa Inggris), terdapat beberapa deretan negara yang menjadikan bahasa Inggris sebagai salah satu pembelajaran wajib disekolah, contohnya: Malaysia, Kenya, Sudan, Filipina, Thailand, Singapore, India, China, korea, tidak terkecuali Indonesia dan masih banyak yang lainnya. Diantara beberapanegara tersebut, mereka memiliki perbedaan tingkatan penggunaan bahasa Inggris. Ada yang menjadikannya sebagai bahasa kedua (second language) salah satu contohnya India dan ada pula yang menjadikannya sebagai bahasa ketiga contohnya Indonesia. Namun hampir seluruh masayarakat Indonesia mengenal dan menyebutnya sebagai bahasa asing. Beberapa alasan kenapa kata "asing" ini melekat dalam bahasa Inggris, yaitu karena cara baca dan penulisannya berbeda, disamping itu satu kata memiliki berbagai bentuk dan makna yang disesuiakan dengan konteks kalimatnya masing-masing dan jarangnya masyarakat mendengar dan menggunakan bahasa Inggris dalam aktivitas kehidupannya sehari-hari.

Dalam pembelajarannya, bahasa Inggris memiliki empat keahlian dasar (four skill) yang harus dimiliki atau dikuasai oleh para siswa. Keempat skill tersebut adalah, listening, writing, speaking and reading. Writing and speaking merupan suatu keahlian yang sangat erat kaitan dengan pemroduksian, baik berupa suara yang dikeluarkan dengan mengungungkapkan atau menyebutkan beberapa kata atau kalimat maupun produk yang berupa, simbol ataupun yang lainnya yang dapat dilihat oleh mata telanjang merupkan produk dari tulisan (writing). Sementara listening and reading merupakan suatu keahlian dalam memperoleh atau menerima pesan. Jadi mereka dapat dianggap sebagai keahlian tanggap atau reseptif.

Berbicara masalah reading (Grabe 1991, dalam Alyouseft, 2005) mendifinisikan membaca sebagai sebuah proses interaktif antara pembaca dan bahan bacaan yang dibacanya yang merupakan hasil dari kemahiran membacanya. Sementara Pang. et al. berpendapat bahwa membaca adalah suatu kegiatan yang kompleks yang melibatkan persepsi dan pemikiran yang terdiri dari pengenalan kata-kata dan proses pemahaman.

Reading atau membaca dimata Anderson adalah interaksi anatara 4 benda yaitu, pembaca, bahan bacaan, kelancaran dan startegi membaca. Sementara dalam pandangannya Nunan (1991) membaca dalam pandangan tradisional, pada dasarnya yaitu dengan cara menafsirkan simbol yang sesuai dengan aura dalam pencarian untuk memahami teks. Definisi membaca juga disampaikan oleh Amir dan Rukaya (1969) yang memaparkan membaca adalah suatu proses penangkapan dan pemahaman ide yang dibaringi dengan curahan jiwa dalam menghayati masalah, makna, nalar dan intuisi yang bekerjasama dalam memahami dan menghayati bacaan.

Berdasarkan beberapa pendapat diatas maka, dapat disimpulkan bahwa membaca adalah suatu proses interaksi antara pembaca dengan bahan bacaan dengan menggunakan kemahiran dan teknik 
mebaca dan dengan melibatkan pemikiran untuk mengindentifikasi simbol, huruf, kata ataupun kalimat, serta menghayati masalah, nalar dan intuisi sehingga memperoleh makna atau pemahaman dari teks tertulis yang dibacanya.

Adapun dua jenis atau bentuk reading yaitu, extensive reading and intensive reading.

1. Extensive reading (membaca dengan ekstensif)

Membaca ekstensif atau yang lebih dikenal kata extensive reading merupakan salah satu jenis membaca dengan mengedapankan atau mempertimbangkan dan atau menyesuikan bahan bacaan dengan kemampuan yang dimiliki. Sehingga ketika seorang pembaca tidak memperhatikan kemampuan yang dimilikinya dalam menyeleksi atau memilih bahan bacaan yang hendak akan dibaca maka orang (pembaca) tersebut akan terpaku pada pengartian atau penafsiran kata demi kata yang merupakan suatu hal baru yang tertera dalam bahan bacaan tersebut.

2. Intensive reading (membaca dengan intensif).

Membaca intensif adalah suatu kegiatan atau peroses membaca dengan menggunakan teks atau bahan bacaan yang lebih banyak atau lebih panjang seta sesui dengan kebutuhan pembaca saat itu. Misalnya mahasiswa yang sedang menekuni dunia pendidikan berati bahan bacaan yang dihendak dibaca atau diberikan tentu harus berkaitan dengan dunia pendidikan atau akademik.

Waring (1997) memaparkan bahwa intensive reading adalah suatu pembelajaran yang sangat penting untuk mempelajari kosakata serta memahami bagaimana bentuk teks. Sementara Dai dan Gao (2012) mengekspresikan bahwa intensive reading untuk meningkatkan reading comprehenssion.

Adapun manfaat membaca menurut Amir dan Rukaya (1996) adalah sebagai berikut

1. Menambah perbendaharaan pengetahuan dan pengalaman hidup

2. Meningkatkan intelektual, kecerdasan serta memperdalam penghayatan ilmu

3. Memperkaya kosakata, dan menambah aperbendaharaan ungkapan yang tepat

4. Memperluas cakrawala pikir dan pandangan

5. Menggugah daya kreatifitas mencipta.

Agar dapat memahami bahan bacaan secara utuh dan cepat, maka seorang pembaca harus miliki skill atau keterampilan dalam membaca. Keterampilan dalam membaca ini biasanya disebut atau dikenal dalam proses belajar dan pembelajaran bahasa adalah pemehaman membaca atau dalam bahasa Inggris biasa disebut sebagai reading comprehenssion.

Reading comprehession atau pemahaman membaca adalah suatu proses penyusunan makna dari bahan bacaan dengan cara penggabungan pengetahuan dan pengalaman sebelumnya, informasi yang terdapat dalam teks dan pandangan pembaca yang berkaitan dengan teks yang sedang dibacanya (Duke, 2003). Sementara reading comprehenssion menurut (Anderson \& Cheng, 1999) adalah sebuah proses mental yang complicated yang membutuhkan keterlibatan kognitif yaitu dari atas kebawah topdown) ataupun sebaliknya dari bawah keatas (bottom-Up). Disamping itu pengertian atau pandangan tentang reading comprehenssion juga datang dari Rand (2002) yang mengemukakan pemahaman membaca adalah sebuah proses elisiting dan pembuatan makna dengan cara terlibat atau berinteraksi secara langsung dengan bahasa tulis.

Jadi reading comprehenssion dapat disimpulkan bahwa suatu proses mental sangat kompleks yang berkaiatan atau berhubungan dengan pembuatan dan penyusunan makna yang melibatkan aspek kognitif melalui penggabungan pengalaman dan pengetahuan sebelumnya dengan pengetahuan yang diperolehnya saat ini (dari bahan bacaan) baik dengan menggukan model menbaca top-down atau bottom-up dengan cara berinteraksi atau terlibat secara langsung dengan bahasa tulis atau teks.

Jika dilihat dari beberapa uraian dia atas baik dilihata dari segi bahasa secara umum maupun dari segi pemahaman membaca atau yang biasa dikenal dengan reading comprehenssion, maka pembelajaran membaca adalah bukan hanya untuk mengenali kata-kata tetapi juga untuk memahami teks atau bahan bacaan (Tierney, 2005). 
Adapun yang menjadi tujuan dalam penulisan artikel ini adalah untuk memamparkan atau menjelaskan kemampuan membaca siswa SMA negeri di kota Bima, faktor-faktor yang dapat mempengaruhi kemampuan membaca, serta hambatan dan solusi dalam proses belajar membaca.

\section{METODE PENELITIAN}

Penilitian ini dilakukan di SMA Negeri di kota Bima dengan melibatkan 74 orang siswa kelas XI dan 2 orang guru sebagai informan yang diambil secara acak yang dilakukan dengan cara dikocok. Penelitian ini merupakan jenis penelitian deskriptif kualitatif dengan menggunakan tehnik pengumpulan data berupa observasi, wawancara dan studi dokumentasi. Sementara tehnik pengolahan atau penganalisian data peneliti menggunakan trianggulasi data dan trianggulasi sumber.

\section{HASIL PENELITIAN DAN PEMBAHASAN}

Berdasarkan hasil penelitian yang telah dilakuka di SMA Negeri di kota Bima yang diperoleh dengan cara interview, pengamatan dan studi dokumentasi. Ketiga pendekatan tersebut digunakian untuk memperoleh informasi-informasi yang berkaitan dengan kemampuan membaca siswa, faktor-faktor yang dapat mempengaruhi proses membaca, serta hambatan dan solusi yang dapat digunakan dalam proses belajar membaca. Dari hasil penelitian tersebut maka didapatlah hasil bahwa.

1. Kemampuan membaca siswa.

Berdasarkan hasil wawancara dengan guru mata pelajaran bahasa Inggris maka diperoleh bahwa hasil pembelajaran bahsa Inggris masih sangat jauh dari hasil yang diharapkan atau masih belum maksimal dalam artian bahwa masih banyaknya siswa yang belum mampu mencapai tujuan pemebelajaran yang telah ditetapkan atau ditentukan sebelumnya. Pernayataan ini didukung oleh kurangnya pemahaman siswa terhadap materi-materi yang telah dipelajarinya. Khususnya pada materi reading. Itu terlihat ketika peneliti menanyakan kepada siswa tentang maksud, arah ataupun inti materi yang dipelajarinya.

Disamping itu kemampuan membaca siswa juga diperoleh dari hasil studi dokumentasi yang silakukan dengan cara melihat dan menganalisis dokumen yang dimiliki oleh guru mata pelajaran bahasa Inggris didua tahun terakhir yaitu 2015-2016 maka diperoleh hasil bahwa hampir rata-rata siswa kelas XI memperoleh nilai rata-rata sebesar 60 , dan jika dilihat dari hasil perolehan tiap individu maka dapat dilihat dari 74 orang siswa hanya sekitar 28 orang siswa atau setara dengan $37,83 \%$ yang mampu mencapai Kriteria Ketuntasan Minimal (KKM) semantara 46 orang sisanya berada dibawah KKM.

Hasil ini jika dijabarkan berdasarkan rentang nilai yang diperoleh yaitu 13 orang siswa atau setara dengan $17,56 \%$ yang memperoleh nilai tinggi dengan rentang nilai $85-100$. Sedangakan 15 orang siswa atau jika dirubah kedalam presentase maka $20,27 \%$ mendapat nilai sedang yaitu dengan rentang nilai $70-80$. Dan sisanya 46 orang siswa atau setara dengan $62,16 \%$ memperoleh nilai rendah yaitu dengan rentang nilai antara 10-65.

2. Faktor-faktor yang dapat mempengaruhi kemampuan membaca.

a. Faktor internal.

Faktor internal merupakan faktor paling utama dalam menentukan keberhasilan sesorang dalam melakukan atau mengerjakan sesuatu, baik itu dalam mengerjakan pekerjaan kantor, pekerjaan rumah, ataupun dalam kegiatan pembelajaran.

Faktor internal ini sangat erat kaitannya dengan motivasi. Motivasi merupakan suatu unsur yang dapat membangkitkan semangat dan dapat mendorong seseorang dalam melakukan sesuatu baik itu pekerjaan maupun pembelajaran. pernyataan ini diperkuat oleh Dalyono (2005) dalam Purwanto (2002) 
mengatakan bahwa orang dapat melakukan segala sesuatu pekerjaan baik yang berasal dari dalam diri maupun dari luar diri adalah pengaruh atau dorongan dari motivasinya. Jadi dapat dipastikan bahwa penyebab dari kurangnya prestasi belajar siswa disebabkan oleh motivasi. Sehingga mereka tidak terdorong untuk terus melakukan prubahan-perubahan dalam diri, baik itu prubahan yang berkaitan erat dengan aspek kognitif, afektif, maupun psikomotorik.

\section{b. Faktor Eksternal}

Faktor eksternal adalah faktor yang berasal dari luar namun juga dapat mempengaruhi perubahan dalam diri seseorang. Faktor eksternal ini bukanlah suatu faktor inti atau faktor kunci yang dapat mendorong seseorang untuk dapat melakukan sesuatu, karena faktor eksternal ini merupakan sebuah faktor tambahan atau faktor pendudkung. Adapun beberapa jenis faktor eksternal ini yang anatara lain meliputi: Orang tua, lingkungan, guru, sarana daan prasarana (buku, Koran, Majalah, Wifi, Lab, Perputakaan dan lain-lain).

\section{Hambatan}

Berdasarkan hasil observasi dan wawancara, maka diperoleh hasil bahwa terdapat beberapa hambatan yang menyebabkan kurangnya pemahaman siswa terhadap pembelajaran reading yang antara lainnya adalah:

a. Proses pembelajaran bahasa Inggris

Berdasarkan hasil observasi dan studi dokumentasi yang dilakukan, baik yang dapat dilihat dari segi perangakat pembelajaran berupa silabus dan RPP maupun dari cara guru dalam mengajar. Pembelajaran bahasa Inggris yang dilakukan disekolah masih menggunakan cara atau metode pembelajaran konvensional. Sementara untuk pemilihan teks-teks atau bahan bacaan yang digunakan guru dalam proses belajar mengajar bahwasannya guru menggunakan teks-teks yang yang dengan kategori tinggi, serta teks-tek yangsangat jarang dijumpai oleh siswa sehingga mereka merasa sangat sulit untuk memahaminya. Salah satu contohnya ketika dalam pembelajaran narrative text guru kebanyakan menggunakan cerita-cerita atau dongeng yang berasal dari daerah diluar daerah Bima seperti cerita Beauty and the beats or Hansel and Gretel sementara kalau dilihat dari sejarah ataupun potensi daerah banyak sekali cerita-cerita rakyak yang berasal dari daerah tersebut (Bima) yang dapat dijadikan sebagai bahan atau sumber belajar. Sehingga dengan pemilihan model atau bahan dan sumber belajar yang tidak sesuai menyebabkan pembelajaran terlihat kaku dan monoton, siswa kurang aktif, bosan dan mengantuk dan acuh tak acuh dalam pembelajaran bahasa Inggris ditambah lagi dengan adanya paradigma yang menyatakan bahwa bahasa Inggris adalah bahasa planet yang sangat sulit untuk dipahami.

b. Penggunaan sumber dan media pembelajaran

Berdasarkan hasil wawancara dengan guru dan siswa sumber belajar yang digunakan si SMA Negeri di kota Bima masih terbatas pada buku paket (look a head) dan lembar kerja siswa (LKS). Sementara media yang digunkannya pun masih terbatas pada flash card, koran dan atau majalah sehingga membuat peserta didik merasa jenuh dan bosan dalam mengikuti pemebelajaran karena hanya memperoleh informasi secara verbal saja tanpa didukung oleh visualisasi yang bagus dan menarik. Keadan ini secara tidak langsung akan berimbas terhadap tingkat pemahaman peserta didik dakam memahami materi yang sedang dipelajari dan terlebih akan berimbas kepada hasil pembelajaran peseta didik. Informasi dari hasil wawancara tersebut dapat dijelaskan sebagai berikut:

1). Penggunaan media pemebelajaran oleh guru masih kurang

2). Pemanfaatan sarana dan prasarana belum maksimal

3). Bahan ajar masih terbatas pada buku paket

4). Peserta didik kurang termotivasi dengan menggunakan media pembelajaran yang verbal dan monoton.

4. Solusi 
Solusi merupakan suatu hal alternatif yang dapat dilakukan untuk menyelesaikan masalah. Jadi berdasarkan hasil penelitian yang telah dilakukan di SMA negeri di Kota Bima maka dapat ditawarkan solusi sebagai berikut:

a. Guru dapat memanfaatkan sarana dan prasarana dengan maksimal

b. Guru dapat menggunakan teks-teks berupa cerita rakyat lokal yang sering jumpai oleh siswa atau dapat mengembangakan materi pembelajaranya sendiri yang disesuiakan dengan kebutuhan dan kemampuan siswa.

c. Guru dapat menggunakan atau mengembangkan media pembelajaran yang inovatif yang ringan, mudah diakses dan dapat digunakan secara berulang-ulang dimana saja dan kapan saja.

\section{KESIMPULAN}

Berdasarkan hasil penelitiannya maka dapat disimpulkan sebagai berikut:

1. Kemampuan belajar siswa.

Berdasarkan hasil studi dokumentasi dan wawancara maka diketahui bahwa kemampuan membaca siswa masih sangat rendah. Itu terlihat rata-rata nilai yang diperoleh siswa sebesar 60 . Jika dijabarkan dari 74 oran siswa hanya 28 orang yang mempu mencapai passing grade (70) sementara 46 sisanya berada dibawah standar.

2. Faktor-faktor yang dapat mempengaruhi pemahaman membaca siswa yaitu:

a. Faktor internal yaitu diri siswa itu sendiri

b. Faktor eksternal yaitu, guru, sumber dan media belajar.

3. Hambatan

Adapun beberapa hambata yang memyebabkan rendahnya reading comprehenssion siswa yaitu:

a. Penggunaan media pemebelajaran oleh guru masih kurang

b. Pemanfaatan sarana dan prasarana belum maksimal

c. Bahan ajar masih terbatas pada buku paket

d. Peserta didik kurang termotivasi dengan menggunakan media pembelajaran yang verbal dan monoton.

4. Solusi

Adapun beberapa tawan solusi yang dapat dilakukan untuk mengatasi masalah rendahnya pemahaman membaca siswa atau yang bisa disebut sebagai reading comprehenssion adalah:

a. Guru dapat memanfaatkan sara dan prasarana dengan maksimal

b. Guru dapat menggunakan teks-teks berupa cerita rakyat lokal yang sering jumpai oleh siswa atau dapat mengembangakan materi pembelajaranya sendiri yang disesuiakan dengan kebutuhan dan kemampuan siswa.

c. Guru dapat meggunakan atau mengembangkan media pembelajaran yang inovatif yang ringan, mudah diakses dan dapat digunakan secara berulang-ulang dimana saja dan kapan saja.

\section{SARAN}

Berdasarkan hasil penelitian yang telah dilakukan sebagaiman tertera dikesimpulan maka, dapat disarankan sebagai berikut:

1. Bagi guru 
a. Guru dapat membuat atau mengembangakan materi pembelajaran sendiri dengan mengangkat tema-tema yang mudah dan cukup weel known bagi siswa dengan mempertimbangkan kebutuhan dan tingkat pemahaman siswa

b. Guru dapat memanfaatkan sarana dan prasarana yang ada disekolah secara maksimal baik sebagai sumber maupun media tambahan bagi siswa

c. Guru dapat menggunakan atau mengembangkan media pembelajaran yang inovatif yang murah, mudah diakases dan dapat digunakan secara berulang sehingga dapat memacu motivasi belajar siswa.

2. Bagi siswa

a. Siswa dapat mencari atau menemukan referensi lain sebagai penunjang pembelajaran disekolah

b. Siswa dapat menggunakan sarana internet (wi-fi) yang disediakan sekolah untuk mengakses atau sumber-sumber belajar

3. Bagi peneliti lain

Dapat melakukan kegiatan penelitian yang lebih lanjut untuk mengembangkan materi maupun media yang kreatif dan innovatif.

\section{DAFTAR PUSTAKA}

Amir \&Rukayah. (1996). Pendidikan Bahasa Indonesia di Kelas Tinggi. Surakarta: FKIP UNS

Anderson, N. J., \& Cheng, X. (1999). Exploring second language reading: Issues and strategies (pp. 5356).

Duke, N. (2003). Comprehension instruction for informational text. Presentation at the annual meeting of the Michigan Reading Association, Grand Rapids, MI.

Grabe, W. (1991). Current developments in second language reading research. TESOL Quarterly. 25 (3), pp.375-406

Nunan, D. (1991). Language teaching methodology: A textbook for teachers. NewYork: Prentice Hall

RAND Reading Study Group. (2002). Reading for under-standing: Toward a research and development program in reading comprehension. Santa Monica, CA: Office of Education Research and Improvement.

Tierney, J. E. (Ed.). (2005). Reading Strategies and Practices (6th ed.). Boston, MA: Pearson Education, Inc.

Waring, R. (1997). Graded and Extensive Reading-Questions and answers. The Language Teaching on line. Available: http://jaH-publications. Ogr/ttl/files//79/may/Waring. Html.

Yang, W., Dai, W.,\& Gao, L. (2012). Intensive Reading and Necessity to Integrate Learning Strategies. English Language and Literature, 2(1), pp. 55-63. http://dx.doi.org/10.5539/ells.v2n1p112 